\title{
Public Health and Advocacy: Lessons from and for Urban Regeneration
}

\section{David Sharp}

Of the seven founders of the American Public Health Association (1872) one was an architect and another a specialist in housing, ${ }^{1}$ and in the UK housing was once a responsibility of the Ministry of Health. So, in the past, in terms of public administration at least, these two important social disciplines were often close knit. The link then broke down and the connection still seems weak today despite much optimism about the role the built environment may have in making populations healthier, especially urban ones. Three years ago, a US Centers for Disease Control and Prevention (CDC) paper conceded that CDC had yet to employ more than a few urban planners, yet it perceived an accelerating reintegration of public health and urban planning. ${ }^{1}$ In the UK, the 15 -member Urban Task Force, headed by architect Richard Rogers and reporting finally in 2005, did not neglect health-related issues but there was no public health professional on board. ${ }^{2}$

According to the CDC paper, one positive result of the "long-term blending of the responsibilities, tools, and eventually perspectives of public health and urban planning" would be "public health professionals increasingly engaging in the urban planning arena" while urban planners do the same in the other direction. There is a touch of chicken-and-egg circularity to this reasoning and in any case some disciplinary boundaries would remain; there is more to urban planning than public health and vice versa. Examples of techniques to be shared include health impact assessments (HIA) and geographic information systems. The latter, well tried in tropical medicine, have been applied to urban projects while the former, often applied in an environmental context, can be used in city planning. In New Zealand, the population in the Christchurch area is predicted to rise by about one-third over the next 40 years and the Greater Christchurch Urban Development Strategy has had an HIA, a process which has itself been scrutinized and, literally, audited (it cost only \$NZ 74,325). ${ }^{3}$ As judged by changes to the master plan, there are glimpses of the obvious ("Avoid severing communities from facilities by major highways"), and, as one might expect, both successes (a new section on health and wellbeing) and disappointments (health indicators not prioritized). The strategy did well with its community involvement, including the Maori minority.

Involving the community in general and ethnic minority groups in particular in urban projects is also an emphasis in a recent paper by Russ P. Lopez from Boston's School of Public Health, in which he reviews the ups and downs of US urban renewal programs and the involvement of the American Public Health Association (APHA) and looks for lessons to be learned for the future. ${ }^{4}$ In 1948, the APHA produced a set of well-intentioned, if imperfect, guidelines for diagnosing blighted

Correspondence: David Sharp, 2 Iron Mills, Minchinhampton, GL6 9AL, UK. (E-mail: davidwsharp@ sky.com)

Sharp is a freelance writer in Minchinhampton, UK. 
neighborhoods. "Cities now had a procedure for targeting neighborhoods for destruction," Lopez notes ruefully. The destruction both of buildings and inner-city societies proceeded apace but finding homes for the displaced populations was not pursued with anything like the same vigor, there being just two new developments (most of them luxury apartments) for every seven housing units destroyed, according to one estimate. If the renewal projects had carried on in the same fashion, which they did not, 4 million people might have been displaced by 1972, African Americans being especially hard hit. Perhaps a lesson here is that to share a tool is not to surrender either ownership of it or responsibility for how it is applied. When cities are shrinking naturally, however, bulldozers may still be needed, as the current US Administration is finding out. ${ }^{5}$

Lopez reckons that public health should shoulder some of the blame for what went wrong with urban renewal and should follow the urban planners in an exercise in critical self-evaluation. Publication of his well-researched historical critique in the APHA's own journal looks like a step in that direction, and it will be interesting to see the response. For one thing, Lopez argues, the professionals "did not rise to defend the poor"; they did not practice advocacy, or did so too late. Yet, some sympathy is due to public health professionals working during the urban renewal era. They may have input into the design of dwellings and urban planning but do not themselves build houses and, though public servants, are employed by city authorities. Blighted neighborhoods and post-industrial rust belts are not unique to the United States, and several European countries have struggled with the same problems, ${ }^{6}$ as Lopez notes.

Writing of a more contemporary issue-the use of mass relocations after natural disasters as an opportunity to screen for illegal immigrants-Lopez sees the need for a strong public health response. "Who else", he asks "has the scientific authority to speak out against potentially destructive government policies?" If science can be said to have authority does this not stem from the dispassionate objectivity of scientific processes? Protesting against misuses is one thing but what if well-intentioned and potentially constructive ideas lack rigorously acquired evidence? For example, public health professionals, as advocates, may well wish to believe that urban renewal as practiced today does have benefits for health. As scientists, however, they must not shy away from the paucity of the evidence to date. Hilary Thomson from the UK's Medical Research Council Social and Public Health Sciences Unit has been injecting just such a healthy "dose of realism" ${ }^{7-9}$ into this debate but not in a destructive way. "Lack of evidence", Thomson writes " is not grounds to abandon the concept of healthy urban policy."7

\section{REFERENCES}

1. Kochtitzky CS, Frumkin H, Rodriguez R, et al. Urban planning and public health at CDC. MMWR. 2006; 55(suppl 02): 34-38.

2. Urban Task Force. Towards a strong urban renaissance. Available at http://www. urbantaskforce.org/UTF_final_report.pdf. Accessed on August 10, 2009.

3. Mathias KR, Harris-Ruxas B. Process and impact evaluation of the Greater Christchurch Urban Development Strategy. BMC Public Health. Epub 2009. doi:10.1186/1471-2458-9-97.

4. Lopez RP. Public health, the APHA, and urban renewal. Am J Public Health. 2009; 99: 2-10.

5. Leonard T. US cities may have to be bulldozed in order to survive. Daily Telegraph (London), June 12, 2009. Available at http://www.telegraph.co.uk/finance/financetopics/financialcrisis/ 
5516536/US-cities-may-have-to-be-bulldozed-in-order-to-survive.html. Accessed August 10, 2009.

6. Verhage R. Renewing urban renewal in France, the UK and the Netherlands. J Housing Built Environ. 2005; 20: 215-227.

7. Thomson H. A dose of realism for healthy urban policy: lessons from area-based initiatives in the UK. J Epidemiol Community Health. 2008; 62: 932-936.

8. Thomson H, Morrison D, Petticrew M. The health impacts of housing-led regeneration: a prospective controlled study. J Epidemiol Community Health. 2007; 61: 211-214.

9. Thomson H, Atkinson R, Petticrew M, Kearns A. Do urban regeneration programmes improve public health and reduce health inequalities? A synthesis of the evidence from UK policy and practice (1980-2004). J Epidemiol Community Health. 2006; 60: 108-115. 